\title{
Clinical signs and symptoms of sexually transmitted infections communicated in Libras*
}

\author{
Sinais e sintomas clínicos de infecções sexualmente \\ transmissíveis comunicados em Libras \\ Señales y síntomas clínicos de infecciones transmitidas \\ sexualmente comunicados en Lengua de Señas
}

Inacia Sátiro Xavier de França ${ }^{1}$, Isabella Medeiros de Oliveira Magalhães ${ }^{2}$, Francisco Stélio de Sousa ${ }^{1}$, Alexsandro Silva Coura', Arthur Felipe Rodrigues Silva², Rosilene Santos Baptista'

How to cite this article:

França ISX, Magalhães IMO, Sousa FS, Coura AS, Silva AFR, Baptista RS. Clinical signs and symptoms of sexually transmitted infections communicated in Libras. Rev Esc Enferm USP. 2016;50(3):456-463. DOI: http://dx.doi.org/10.1590/S0080-623420160000400012

\footnotetext{
* Extracted from the end-of-course paper "Comunicação em Libras: sinais e sintomas relacionados a infecções sexualmente transmissíveis", Undergraduate Nursing Program, Universidade Estadual da Paraíba, 2014.

${ }^{1}$ Universidade Estadual da Paraíba, Departamento de Enfermagem, Campina Grande, PB, Brazil

${ }^{2}$ Universidade Estadual da Paraíba, Programa de Pós-Graduação em Saúde Pública, Campina Grande, PB, Brazil.
}

\begin{abstract}
Objective: To validate a video containing image representations of clinical signs and symptoms of sexually transmitted infections expressed in Libras. Method: Methodology development study conducted in an audio communication school. Thirty-six deaf people were selected. A video containing image representations of clinical signs and symptoms of sexually transmitted infections expressed in Libras was produced. Semantic validation was performed by deaf students and content validation by three judges who are Libras experts. The validation results were subjected to the Content Validity Index, where an index score $\geq 0.80 / 80 \%$ was considered as agreement among judges. Results: Seven signs and symptoms related to sexually transmitted infections were validated and obtained satisfactory Content Validity Indexes, most of them with $100 \%$ representativeness and agreement. Conclusion: The validation process made the expressions of signs and symptoms related to sexually transmitted infections represented in Libras valid for establishing effective communication in the area of the study, turning it into a care tool that facilitates and standardizes communication with deaf people through Libras.
\end{abstract}

\section{DESCRIPTORS}

Deafness; Hearing Loss; Nursing Care; Sexually Transmitted Diseases; Validation Studies.
Corresponding author:

Inacia Sátiro Xavier de França

Universidade Estadual da Paraíba.

Centro de Ciências Biológicas e da Saúde,

Departamento de Enfermagem.

Rua Juvêncio Arruda S/N, Campus

Universitário, Bodocongó

CEP 58429-600 - Campina Grande, PB, Brazil

inacia.satiro@gmail.com
Received: 08/06/2015

Approved: 04/20/2016 


\section{INTRODUCTION}

Deafness is a global public health problem. Most of the 360 million people with disabling hearing loss live in low and medium income level countries. In 2010, it was calculated that $21.31 \%$ of people in Brazil experience some sort of deafness ${ }^{(1)}$. Deafness is a problem resulting from reduced sensitivity or auditory discrimination, characterized by partial or complete loss of hearing ability, which can manifest in different degrees: mild, moderate, severe or profound ${ }^{(2)}$.

In Brazil, with the advent of legal assurances for deafness prevention, treatment and rehabilitation of those with hearing loss, sufferers can count on improvements in the communication process due to the increase in audiological procedures. Despite these efforts by the state, authors report discrepancies in the provision of such services, which are the most prevalent in the Southeast, Northeast and South regions. These authors also report unequal access to care for people with hearing loss due to the fledgling supply of accredited hearing care units in each federal region, especially in the North and Center-West regions, which breaches the principles of comprehensive and universal care of the Unified Health System (SUS) ${ }^{(3)}$.

Deafness impairs or prevents understanding of speech, requiring people with this problem to use strategies to ensure communication with their environment. Regardless of the manifestation of deafness, human beings, from birth, seek to develop communication strategies. In childhood, natural gestures, used in the pre-linguistic stage, are one of communication strategies for expressing ideas without words. After this stage, natural gestures support language acquisition, and take on a complementary role in language. In the deaf community, sign language is a codified system of gestures with all the characteristics of spoken language $e^{(4)}$.

Hearing people, however, do not usually have proficiency in the sign language used by deaf people. This is because the reception and production channels of oral languages and sign languages differ: whereas with spoken languages these channels are the ears and phono-articulation system, with sign languages they are the eyes and hands ${ }^{(5)}$. These characteristics of sign language contribute to making the deaf person's social condition a place of disability, limitation and inferiority, relegating deafness to a problem of disability $^{(6)}$. As a result of these disadvantages, people with disabilities are considered vulnerable, such that stereotypical discussions about their sexuality can lead to conclusions that they are being sexually abused, even when sex is desired and consensual ${ }^{(7)}$.

With regard to health concerns, people with disabilities have an increased risk of being exposed to HIV, due to lack of access to prevention, treatment and sex education ${ }^{(8)}$. As far as the conduct of health professionals in meeting the needs of these people, a report from a study conducted in São Paulo, Brazil, shows that women with disabilities receive inferior primary care services, due to low valuation of their sexual and reproductive rights and their dual vulnerability for being women and suffering from a disability.
The complaints reported by the women include: rejection or overprotection by their families, difficulties to study and qualify themselves professionally, in addition to obstacles to experience sexuality and motherhood ${ }^{(9)}$.

Furthermore, there are few studies that address sexual and reproductive life, or the socio-cultural determinants of the sexual lives, including unprotected sex, of people with disabilities. As a rule, studies focus on sexual violence against people with mental disabilities ${ }^{(10)}$. However, sexually transmitted infections (STIs) affect people of both sexes, from all ethnic groups and every social level, and are transmitted through intimate contact with an infected person. This means that, in the case of the deaf, health professionals need to use Brazilian Sign Language, also known as Libras, to care for and empower them to live healthy sexual and reproductive lives.

In Brazil, deaf people use Libras, the study and teaching of which is disseminated in higher education institutions under Law 10436/ 02 ${ }^{(11)}$, which recommends offering Libras as a curricular discipline in Special Education, Teaching and Speech Therapy courses. These legal assurances also establish that the SUS must ensure comprehensive health care for people with hearing disabilities, for different levels of complexity and medical specialties, to guarantee support for the training and education of professionals working in the SUS network, in the use of Libras and its translation and interpretation.

Although Law 10436 / 2002 is in full force, the authors of a study conducted with a sample of 25 undergraduate courses in the health area, offered by higher education institutions located in northeastern Brazil, found that the pedagogical structure of these courses sought to train and equip professionals with the necessary expertise and skills for professional practice, without referring to the teaching of $\mathrm{Libras}^{(12)}$.

The lack of interpreters and health professionals trained to communicate with the deaf is a problem in health care. Added to this, are the social determinants that hinder these users from partaking of health assets and services. This situation is corroborated by British researchers who studied the health conditions of 298 deaf adult users of British Sign Language (BSL). The report from this study noted that deaf people face great difficulties in health care access and communication during medical visits. In addition, the health of these participants, when compared with the general population, is poor, and exposes them to preventable health problems ${ }^{(13)}$.

There is a clear need for studies focusing on the use of Libras so that socialization of the results may contribute to improved communication between the deaf and health professionals. From this perspective, the following question guided this study: How do the deaf express clinical signs and symptoms of sexually transmitted infections in Libras?

In this regard, the study is relevant because issues related to affective-sexual experiences and sexually transmitted diseases and AIDS have been the subject of scientific literature in health and are highly discussed topics in Brazilian society. Another reason is that regardless of the legal provisions 
recommending the use of Libras in health services, compliance with the guidelines of these legal documents continues to fall short. This is why socializing the results of studies demonstrating the expression, in Libras, of STI signs and symptoms, contributes to the training of nursing professionals in terms of making them more qualified to meet the basic needs of this social segment.

Based on the assumption that deaf people face communication difficulties in health services, and that some health professionals lack knowledge of Libras, which affects the care given to the deaf, the objective of this study was to validate a video containing image representations of clinical signs and symptoms of sexually transmitted infections expressed in Libras.

\section{METHOD}

This study is part of a larger study, entitled Comunicação com o surdo: contribuição à assistência de enfermagem mediada pela lingua de sinais [Communication with the deaf: contribution to nursing care mediated by sign language], submitted in response to Notice 02/2010 of the Incentive Program for Graduate Studies and Research (PROPESq), for 2011/2012, financed by the Universidade Estadual da Paraíba and approved under No. 048/2011.

It was a methodological development study conducted in 2012, at Escola de Audiocomunicação Demóstenes Cunha Lima (EDAC - audio communication school) located in the city of Campina Grande, in the state of Paraíba, Brazil. This institution, which started operating in 1983, is affiliated with the Department of Municipal Education and the Federal University of Campina Grande, Paraíba, Brazil. EDAC offers elementary and secondary education to 264 deaf students enrolled. Its objectives include: teach and use Libras to enhance the acquisition of knowledge within the pedagogical structure of the courses and facilitate the process for deaf students to learn written language.

After authorization from EDAC, the dates and times for data collection were scheduled. The following people were selected: a) a random group of 36 deaf people; b) a group of three judges (Libras teachers and interpreters), invited according to accessibility; c) two deaf people who knew Libras and how to use it to reproduce the signs and symptoms of STIs.

The researchers decided to invite an odd number of judges to avoid ambiguous issues in case of a tie. The general eligibility criteria for inclusion in the above two groups were: being 18 years old or older, being proficient in Libras and knowing Portuguese.

With respect to the Libras judges, two specific inclusion criteria were added. The first was to have Prolibras - a national exam for Libras proficiency certification. This exam certifies deaf or hearing people fluent in Libras, who have completed university or high school, such as Libras instructors, and recognizes their competence in the use and teaching of this language or in its translation and interpretation. The second was to have a formal employment relationship with EDAC, as a teacher.
In the initial phase of building the content, there was a literature review and Questionnaire I was administered to the deaf participants, containing the variables: gender, age, marital status, level of education, job, household income, housing conditions, leisure, smoking, alcohol use, family medical history, previous signs and symptoms of health issues and STI-related signs and symptoms. The language used to identify the clinical signs and symptoms was not the standard one used by health professionals, but rather a simple and clear language based on common sense that would be better understood by some of the deaf students, as well as the Libras judges, since both were unfamiliar with some of the specific technical terms used in the health field.

Eight signs and symptoms related to STIs were compiled, which were reproduced in Libras, by two of the deaf students selected. This representation was filmed and recorded on video, and then presented to the deaf participants from the sample for semantic evaluation using an instrument with the signs and symptoms contained in the film, accompanied by the options ( ) YES or ( ) NO. Marking the answer YES was interpreted as Excellent, worth 5 points, and considered a relevant and representative item. Marking the answer NO, meaning Very Poor, worth 1 point, was considered as not relevant and not representative.

Following this, the film validated by the deaf participants was submitted to the judges for their consideration. The instrument used by the judges was a Likert scale, containing a list of the eight clinical signs and symptoms reproduced by the deaf students, with a scoring range from 1 to 5 , corresponding to the following concepts: Very poor: not relevant and not representative, with a score of 1 point; Poor: not relevant or not representative, with a score of 2 points; Average: item requires major revision to be representative, with a score of 3 points; Good: item needs little revision to be representative, with a score of 4 points; Excellent: relevant or representative item, with a score of 5 points.

The results obtained from the judges were analyzed using the Content Validity Index (CVI), which measures the proportion or percentage of judges who are in agreement on certain aspects of the instrument and its items. The following formula was used to obtain the CVI: CVI = number of responses " 4 " or “ 5 "/total number of responses ${ }^{(14)}$.

Items which achieved a score with an agreement rate $\geq 0.80 / 80 \%$ among the judges were considered validated $^{(15)}$. The score of 1 was applied, representing $100 \%$ agreement among the judges participating in the validation process. The validated content results were transformed into drawings and presented in figures.

The project was submitted to and approved by the Research Ethics Committee of the State University of Paraíba, CAAE No. 0700.0.133.000-11. Participants were explained about the researchers, the objectives and benefits of the study, assurances regarding the confidentiality and privacy of information related to personal identification and their right to drop out of the study at any time, without any kind of onus. Each participant signed a free and informed consent form, wherein it was also explained that the images 
resulting from the study would be recorded on video for use in publications to socialize the images.

\section{RESULTS}

A total of 36 deaf people were studied, in an age range from 18 to 36 years, being 23 men and 13 women, among whom 30 were single. There were 27 workers who earned from one to two minimum wages and 20 of them were from ages 18 to 23 .

The STI signs and symptoms referred to by the deaf students as known ones were the following: vaginal discharge, discharge via the urethra, pain during sexual intercourse, sore in the male genital region, sore in the female genital region, small blisters in the male genital region, small blisters in the female genital region and bleeding during sexual intercourse.

In terms of the semantic validation of the expressions in Libras of these signs and symptoms contained in the film, all the deaf participants from the assigned group selected the images expressed by the two deaf students as true and reliable, marking them with a YES on the questionnaire. Therefore, this consolidated material was scored as excellent (5) and obtained a score of 1 , with $100 \%$ representativeness and agreement.

This result slightly dissents with the evaluation of the filmed content by the Libras judges as far as the scores attributed to each clinical sign and symptom related to STIs expressed by deaf persons 1 and 2 .

Table 2 presents the results of the CVI calculation, based on the evaluation of the video by the deaf participants and Libras judges. It was noted that there were 45 " 4 " or " 5 " responses out of a total of 48 , resulting in an overall CVI of 0.94 .

Figure 1 presents the validated symbolic images of the signs and symptoms related to STIs contained in the video which were considered valid in the CVI calculation.

Table 1 - Score assigned by the judges to the expressions of clinical signs and symptoms of STIs in Libras, EDAC - Campina Grande, PB, Brazil, 2012.

\begin{tabular}{|c|c|c|c|c|c|c|c|}
\hline \multirow{2}{*}{ SIGNS AND SYMPTOMS } & \multicolumn{3}{|c|}{ Deaf person 1} & \multicolumn{3}{|c|}{ Deaf person 2} & \multirow{2}{*}{$\%$} \\
\hline & $\mathbf{J 1}$ & J2 & J3 & $\mathbf{J 1}$ & $\mathbf{J} 2$ & J3 & \\
\hline Pain during sexual intercourse & 4 & 5 & 5 & 5 & 5 & 5 & 100 \\
\hline Vaginal discharge & 5 & 5 & 3 & 5 & 3 & 5 & 66.6 \\
\hline Bleeding during sexual intercourse & 5 & 5 & 5 & 5 & 5 & 3 & 83.3 \\
\hline Sore in the male genital region & 5 & 5 & 5 & 5 & 5 & 5 & 100 \\
\hline Sore in the female genital region & 5 & 5 & 5 & 5 & 5 & 5 & 100 \\
\hline Discharge via the urethra & 5 & 5 & 5 & 5 & 5 & 5 & 100 \\
\hline Small blisters in the male genital region & 5 & 5 & 5 & 5 & 5 & 5 & 100 \\
\hline Small blisters in the female genital region & 5 & 5 & 5 & 5 & 5 & 5 & 100 \\
\hline
\end{tabular}

Source: Research data. $\mathrm{J} 1$ = judge $1 ; \mathrm{J} 2$ = judge $2 ; \mathrm{J} 3$ = judge 3 .

Table 2 - Content Validity Index (CVI) for the clinical signs and symptoms of STIs expressed in Libras, EDAC - Campina Grande, PB, Brazil, 2012.

\begin{tabular}{|c|c|c|c|c|c|}
\hline \multirow{2}{*}{ Signs and symptoms } & \multicolumn{2}{|c|}{ CVI Deaf persons* } & \multirow{2}{*}{$\begin{array}{c}\begin{array}{c}\text { Semantic evaluation of } \\
\text { the video }\end{array} \\
\text { Deaf persons } 1 \text { and } 2\end{array}$} & \multirow{2}{*}{$\begin{array}{c}\begin{array}{c}\text { Representativeness and } \\
\text { agreement }\end{array} \\
(\%)\end{array}$} & \multirow{2}{*}{ Overall CVI } \\
\hline & 1 & 2 & & & \\
\hline Pain during sexual intercourse & 1 & 1 & 1 & 100 & 0.94 \\
\hline Vaginal discharge & 0.66 & 0.66 & 1 & 66.66 & \\
\hline Bleeding during sexual intercourse & 1 & 0.66 & 1 & 83.33 & \\
\hline Sore in the male genital region & 1 & 1 & 1 & 100 & \\
\hline Sore in the female genital region & 1 & 1 & 1 & 100 & \\
\hline Discharge via the urethra & 1 & 1 & 1 & 100 & \\
\hline Small blisters in the female genital region & 1 & 1 & 1 & 100 & \\
\hline
\end{tabular}

Source: Research data. *Judges' agreement with the expressions of deaf persons 1 and 2. 

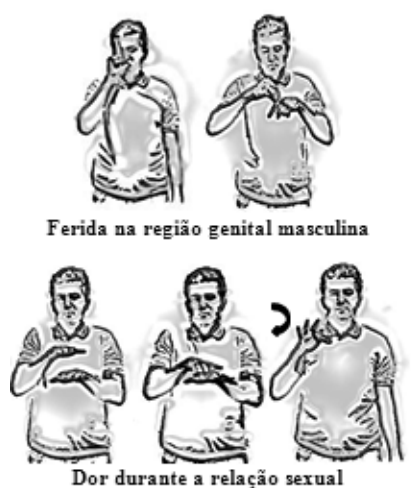

Dor durante a relação sexual

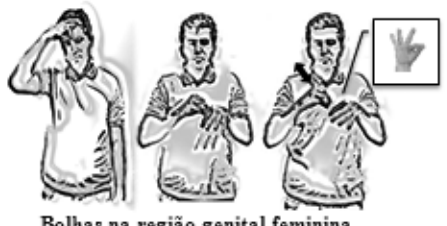

Bolhas na região genital feminina

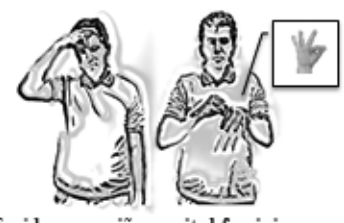

Ferida na região genital feminina
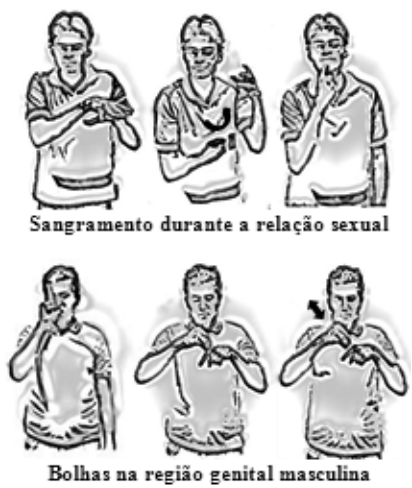

Bolhas na região genital masculina

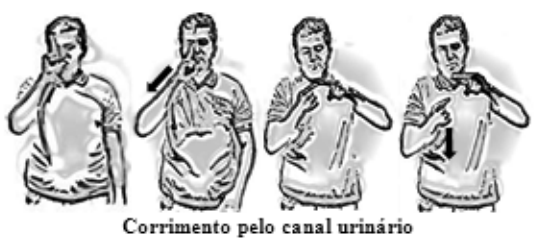

Figure 1 - Clinical signs and symptoms of STIs expressed in Libras by the deaf students and validated by the Libras judges.

\section{DISCUSSION}

The sociodemographic profile in this study corroborates what was reported in the literature, where most are single men, between 18 and 35 years old, unemployed, with eight years of education and a monthly income below two minimum wages ${ }^{(16)}$.

During the production of the video, these deaf participants expressed little knowledge about the signs and symptoms of the STIs. However, this finding differs from that of another study in Paraíba, involving 300 women with active sex lives, where it was detected that they had insufficient knowledge about STIs ${ }^{(17)}$. It also differs from the results of a study on the social representations of deaf adolescents regarding sexual activities and the health-disease process, in that the authors report that most of these participants are uninformed and confused in terms of dealing with diseases, especially STIs ${ }^{(18)}$.

These findings indicate the need for intervention through health education, to increase knowledge about these diseases and how to prevent them. This need is also supported by reports that, in the contemporary social context, media is used to expose people to different sex-related situations, without them being properly informed, in regard to their sexual lives and the potential risks involved in the sexual practice. This phenomenon requires that health professionals seek to understand this problem and develop methods and materials accessible to those people who are susceptible to STDs, especially HIV/AIDS ${ }^{(19)}$.

In the validation of the signs and symptoms expressed by the deaf students, the judges from the study sample were qualified, since all three have Prolibras certification, as well as teaching experience with Libras, working as teachers linked to EDAC. In turn, the deaf students who participated were an important factor in the rich and integrated partnership with the judges, due to the everyday use of Libras at EDAC and within the deaf community, thus demonstrating the necessary knowledge and skills to express the clinical signs of the STIs that were presented to them, contributing on both a theoretical and practical level.

All the judges were in agreement with the aspects of the questionnaire and its items and considered the instructions for filling it out to be adequate, enabling an analysis of each item individually and, then, the questionnaire as a whole. They also did not request any changes to the images presented.

Of the eight images of clinical signs and symptoms related to STIs expressed in Libras, six were excellent in terms of representativeness and agreement, with the maximum CVI, making them representative and valid for use in a clinical environment. However, two images expressed in Libras - vaginal discharge and bleeding during sexual intercourse - did not obtain full agreement and representativeness among the judges. The lower scores for these two image expressions suggest the need for further consideration and analysis when used in the patient care environment, since, besides helping to identify the symptoms of possible sexually transmitted infections they can also be used for health education.

In this regard, the experts' validation made the expressions of signs and symptoms of STIs in Libras suitable for establishing effective communication between health 
professionals and the deaf in the city of Campina Grande (PB), Brazil, through proper use of the criteria: expression, understanding and accuracy of the signals.

In addition to the content validation performed in this study, it must be added that health professionals, especially nurses, need to seek training in Libras to provide the deaf with systematized and humanized quality care and break down existing communication barriers. This need is corroborated in another study which notes that all of the participants reported difficulty interacting with health professionals, communicating mainly through the assistance of a relative, or using lip reading, images or mimicry ${ }^{(16)}$.

Deaf participants in another study in Paraíba, in the northeast region of Brazil, mentioned the use of writing, lip reading and, especially, the presence of a family member as communication strategies used by health professionals when providing care. They also referred to the loss of privacy and the right to understand their health-disease process, as well as the ineffectiveness of these communication strategies for their full integration and participation in society ${ }^{(20)}$.

It is worth noting that communication with the deaf, when mediated by an accompanying person or interpreter, besides breaking the professional-patient bond, hinders access to information and direct contact with the patient, thereby breaching the confidentiality of the issues related to the latter. Apart from this ethical issue, there are other factors that contribute to the difficulties in the care given by nurses to the deaf, such as unfavorable working conditions, the limitations of the deaf themselves and the values and understanding on the part of the deaf and nurses, in addition to meta-contextual conditions represented by public policies ${ }^{(21)}$.

Finally, authors report the need for more studies related to deafness, focusing on all the professionals involved in the direct care of deaf patients, since it is important that all communication be effective. A communication program is also needed for people with hearing loss of any degree and nature, so that they can know and use Libras, as well as posters and signs with sign systems, to enable them to have access to the information they need when visiting a health unit ${ }^{(22)}$.

\section{CONCLUSION}

In this study, the representations of the following STI signs and symptoms in Libras were validated: pain during sexual intercourse, bleeding during sexual intercourse, sore in the male genital region, sore in the female genital region, discharge via the urethra, small blisters in the male genital region and small blisters in the female genital region. The representation of discharge via the urethra did not meet the parameters established for the validation, with changes needed for a new validation procedure.

The results of this study demonstrate that the proposed objectives were achieved and the guiding question was answered, which was to represent, in Libras, the clinical signs and symptoms of STI's, whose images were validated by judges. The use of these validated images, at any level of care, creates a positive link between deaf people and health professionals. Therefore, the main contribution of the study is that it provides health professionals with a health care tool that facilitates developing the care provided to deaf people, by enabling efficient and effective direct communication between the deaf and health professionals.

The limitations of the present study stemmed from the lack of similar studies in the databases consulted, to establish convergences, similarities or distances between the results. Validation results were found, but with different and divergent themes than those studied here. In addition, the findings of this study, which pertain to a specific social segment, characterized as the deaf, cannot be generalized for the plural society.

Deaf people's knowledge about STIs requires professional proximity so that they can discuss this topic. Such proximity must be a continuous process, with an emphasis on sexual and reproductive rights and proficiency in Libras, which requires interdisciplinary training of professionals working in health services to overcome the shortcomings identified, as a result of communication difficulties.

Future studies on this topic are recommended, as well as other samples of deaf people and judges in different scenarios, to make signs and symptoms of diseases expressed in Libras a consolidated tool that is used in care practices and health education.

\section{RESUMO}

Objetivo: Validar um vídeo contendo as representações imagéticas de sinais e sintomas clínicos de infecções sexualmente transmissíveis expressas em Libras. Método: Estudo de desenvolvimento metodológico, realizado em uma escola de audiocomunicação. Selecionou-se uma amostra de 36 surdos. Elaborou-se um vídeo contendo a representação imagética de sinais e sintomas de infecções sexualmente transmissíveis expressos em Libras. A validação semântica foi realizada pelos surdos e a validação de conteúdo por três juízes experts em Libras. Os resultados da validação foram submetidos ao Índice de Validade de Conteúdo, considerando-se o escore do índice $\geq 0,80 / 80 \%$ de concordância entre os juízes. Resultados: Foram validados sete sinais e sintomas relacionados às infecções sexualmente transmissíveis que obtiveram Índices de Validade de Conteúdos satisfatórios e em sua maioria com 100\% de representatividade e concordância. Conclusão: O processo de validação tornou válidas as expressões de sinais e sintomas relacionados às infecções sexualmente transmissíveis representadas em Libras para estabelecer, na região do estudo, uma comunicação eficiente, tornando-se uma ferramenta assistiva que permite facilidade e uniformidade na comunicação com os surdos por meio da Libras.

\section{DESCRITORES}

Surdez; Perda Auditiva; Doenças Sexualmente Transmissíveis; Estudos de Validação.

\section{RESUMEN}

Objetivo: Validar un video conteniendo las representaciones imagéticas de señales y síntomas clínicos de infecciones transmitidas sexualmente expresados en Lengua de Señas. Método: Estudio de desarrollo metodológico, llevado a cabo en escuela de audiocomuni- 
cación. Se seleccionó una muestra de 36 sordos. Se elaboró un video conteniendo la representación imagética de señales y síntomas de infecciones transmitidas sexualmente expresados en Lengua de Señas. La validación semántica fue realizada por los sordos y la validación de contenido por tres jueces expertos en Lengua de Señas. Los resultados de la validación fueron sometidos al Índice de Validez de Contenido, considerándose el puntaje del índice $\geq 0,80 / 80 \%$ de concordancia entre los jueces. Resultados: Fueron validados siete señales y síntomas relacionados con las infecciones transmitidas sexualmente que obtuvieron Índices de Validez de Contenidos satisfactorios y en su mayoría con el 100\% de representatividad y concordancia. Conclusión: El proceso de validación hizo válidas las expresiones de señales y síntomas relacionados con las infecciones transmitidas sexualmente representadas en Lengua de Señas para establecer, en la región del estudio, una comunicación eficiente, convirtiéndose en una herramienta asistiva que permite facilidad y uniformidad en la comunicación con los sordos por medio de la Lengua de Señas.

\section{DESCRIPTORES}

Sordera; Pérdida Auditiva; Atención de Enfermería; Enfermedades de Transmisión Sexual; Estudios de Validación.

\section{REFERENCES}

1. Instituto Brasileiro de Geografia e Estatística. Censo 2010. Rio de Janeiro: IBGE; 2010.

2. Castro SS, Paiva KM, César CLG. Communication difficulties between individuals with hearing disability and health professionals: a public health matter. Rev Soc Bras Fonoaudiol [Internet]. 2012 [cited 2015 July 10];17(2): 128-34. Available from: http://www.scielo.br/pdf/rsbf/ v17n2/en_05.pdf

3. Andrade CL, Fernandes L, Ramos HE, Mendes CMC, Alves CAD. Programa Nacional de Atenção à Saúde Auditiva: avanços e entraves da saúde auditiva no Brasil. Rev Ciênc Med Biol [Internet]. 2013 [citado 2015 jul. 11];12(n.esp): 404-10. Disponível em: http://www. portalseer.ufba.br/index.php/cmbio/article/viewFile/9181/6749

4. Lima ERS, Cruz-Santos A. Aquisição dos gestos na comunicação pré-linguística: uma abordagem teórica. Rev Soc Bras Fonoaudiol [Internet]. 2012 [citado 2015 jul. 03];17(4):495-501. Disponível em: http://www.scielo.br/pdf/rsbf/v17n4/22.pdf

5. Sales AS, Oliveira RF, Araújo EM. Inclusão da pessoa com deficiência em um Centro de Referência em DST/AIDS de um município baiano. Rev Bras Enferm. 2013;66(2):208-14.

6. Abreu FSD, Silva DNH, Zuchiwschi J. Surdos e homossexuais: a (des)coberta de trajetórias silenciadas. Temas Psicol [Internet]. 2015 [citado 2016 fev. 22]; 23(3):607-20. Disponível em: http://pepsic.bvsalud.org/pdf/tp/v23n3/v23n3a07.pdf

7. Dantas TC, Silva JSS, Carvalho MEP. Entrelace entre gênero, sexualidade e deficiência: uma história feminina de rupturas e empoderamento. Rev Bras Educ Espec [Internet]. 2014 [citado 2015 jul. 10];20(4):555-68. Disponível em: http://www.scielo.br/pdf/rbee/v20n4/a07v20n4.pdf

8. Reus L, Hanass-Hancock J, Henken S, Brakel W. Challenges in providing HIV and sexuality education to learners with disabilities in South Africa: the voice of educators. Sexual Soci Learn. 2015;15(4):333-47.

9. Nicolau SM, Schraiber LB, Ayres JRCM. Mulheres com deficiência e sua dupla vulnerabilidade: contribuições para a construção da integralidade em saúde. Ciênc Saúde Coletiva [Internet]. 2013 [citado 2015 ago. 03];18(3):863-72. Disponível em: http://www.scielo.br/ $\mathrm{pdf} / \mathrm{csc} / \mathrm{v} 18 \mathrm{n} 3 / 32 . \mathrm{pdf}$

10. Souto RQ, Leite CCS, França ISX, Cavalcanti AL. Violência sexual contra mulheres portadoras de necessidades especiais: perfil da vítima e do agressor. Cogitare Enferm. 2012;17(1):72-7.

11. Brasil. Lei n. 10.436, de 24 de abril de 2002. Dispõe sobre a Língua Brasileira de Sinais - Libras - e dá outras providências [Internet]. Brasília; 2002 [citado 2015 Maio 20]. Disponível em: http://www.planalto.gov.br/ccivil_03/leis/2002/L10436.htm

12. Oliveira YCA, Costa GMC, Coura AS, Cartaxo RO, França ISX. A língua brasileira de sinais na formação dos profissionais de enfermagem, fisioterapia e odontologia no estado da Paraíba, Brasil. Interface Comun Saúde Educ [Internet]. 2012 [citado 2015 ago. 03];16(43):9951008. Disponível em: http://www.scielo.br/pdf/icse/v16n43/aop4712.pdf

13. Emond A, Ridd M, Sutherland H, Allsop L, Alexander A, Kyle J. The current health of the signing Deaf community in the UK compared with the general population: a cross-sectional study. BMJ Open. [Internet]. 2015 [cited 2016 Feb 22];5(1). Available from: http://bmjopen. bmj.com/content/5/1/e006668.full

14. Alexandre NMC, Coluci MZO. Validade de conteúdo nos processos de construção e adaptação de instrumentos de medidas. Ciênc Saúde Coletiva [Internet]. 2011 [citado 2015 jul. 03];16(7):3061-68. Disponível em: http://www.scielo.br/pdf/csc/v16n7/06.pdf

15. Grant JS, Davis LL. Selection and use of content experts for instrument development. Res Nurs Health. 1997;20(3):269-74.

16. AragãoJS, Magalhães IMO, CouraAS, SilvaAFR, CruzGKP, Franca ISX.Accessand communication of deafadults: a voicesilenced in health services.J Res Fundam Care [Internet]. 2014 [cited 2015 Jul 15]; 6(1):1-7. Available from: http://www.seer.unirio.br/index.php/cuidadofundamental/ article/view/2989

17. Andrade SSC, Zaccara AAL, Leite KNS, Brito KKG, Soares MJGO, Costa MML, et al. Knowledge, attitude and practice of condom use by women of an impoverished urban area. Rev Esc Enferm USP [Internet]. 2015 [cited 2015 Aug 02]; 49 (3): 364-71. Available from: http:// www.scielo.br/pdf/reeusp/v49n3/0080-6234-reeusp-49-03-0364.pdf 
18. Collazos Aldana J. Representaciones sociales de la salud de adolescentes sordos en la ciudad de Bogotá. Pensamiento Psicol [Internet]. 2012 [citado 2016 fev. 22]; 10(2). Disponible em: http://revistas.javerianacali.edu.co/index.php/pensamientopsicologico/article/view/415

19. Sales AS, Oliveira RF, Araújo EM. Inclusão da pessoa com deficiência em um Centro de Referência em DST/AIDS de um município baiano. Rev Bras Enferm [Internet]. 2013 [citado 2016 fev. 22];66(2):208-14. Disponível em: http://www.scielo.br/pdf/reben/v66n2/09.pdf

20. Oliveira YCA, Celino SDM, Costa GMC. Comunicação como ferramenta essencial para assistência à saúde dos surdos. Physis Rev Saúde Coletiva [Internet]. 2015 [citado 2015 maio 27];25(1):307-20. Disponível em: http://www.scielo.br/pdf/physis/v25n1/0103-7331physis-25-01-00307.pdf

21. Araújo CCJ, Coura AS, França ISX, Araújo AKF, Medeiros KKAS. Consulta de Enfermagem às pessoas surdas: uma análise contextual. ABCS Health Sci. [Internet]. 2015 [citado 2016 fev. 22];40(1):38-44. Disponível em: http://www.portalnepas.org.br/abcshs/article/view/702/667

22. Magrini AM, SantosTMM. Comunicação entre funcionários de uma unidade de saúde e pacientes surdos: um problema? Disturb Comum [Internet]. 2014 [citado fev. 22];26(3):550-8. Disponível em: http://revistas.pucsp.br/index.php/dic/article/view/14880 